Pivit Septiary Chandra, Sonia Sischa Eka Putri I Analisis Pelaksanaan Kebijakan Kota Layak Anak (Studi Kasus Pelaksanaan Program Ruang Bermain Ramah Anak di Ruang Terbuka Hijau Kacang Mayang Kota Pekanbaru)

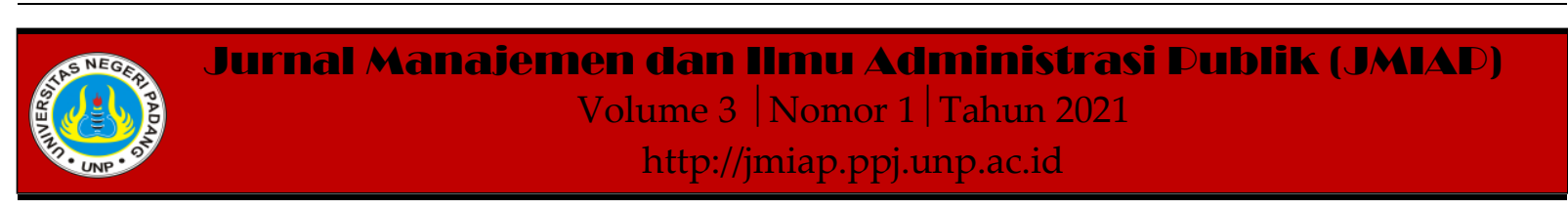

\title{
ANALISIS PELAKSANAAN KEBIJAKAN KOTA LAYAK ANAK (STUDI KASUS PELAKSANAAN PROGRAM RUANG BERMAIN RAMAH ANAK DI RUANG TERBUKA HIJAU KACANG MAYANG KOTA PEKANBARU)
}

\author{
Pivit Septiary Chandra ${ }^{1(a)}$, Sonia Sischa Eka Putri ${ }^{2(b)}$ \\ ${ }^{1}$ Jurusan Administrasi Negara, Universitas Islam Negeri Sultan Syarif Kasim Riau \\ ${ }^{2}$ Jurusan Akuntansi, Universitas Islam Negeri Sultan Syarif Kasim Riau \\ ${ }^{a)}$ pivit.s.chandra@uin-suska.ac.id, ${ }^{b}$ sonia.sischa@uin-suska.ac.id
}

\begin{abstract}
As a form of Child Friendly City policy, the Child Friendly Playroom (RBRA) program is realized. Pekanbaru's achievement as a city that provides certified child-friendly play spaces is a manifestation of its initial commitment to building and giving children the right to develop and develop children in its playground located at RTH Kacang Mayang, Pekanbaru City. This study aims to see the implementation of child-friendly city policies in the Kacang Mayang Green Open Space, Pekanbaru City. This type of research is qualitative with descriptive analysis. Qualitative research is a research procedure that produces descriptive data in the form of written or spoken words from people and observed behavior from the phenomena that occur. This study examines the facts of the implementation of the Child Friendly Playroom Program in Pekanbaru City. The data collection technique in this research uses literature study by collecting data and documents from various references that will be used as references. The results of this study are that the implementation of child-friendly city policies ( $a$ case study of the implementation of the Child Friendly Playroom Program in the Kacang Mayang Green Open Space in Pekanbaru City) has gone well. This is shown by the availability of adequate facilities, infrastructure and facilities to become child-friendly green open spaces. Received a good assessment and determined that Pekanbaru's Kacang Mayang Green Open Space was suitable for children, proving the government's commitment to realizing a child-friendly city through the provision of child-friendly green open spaces. In implementing child-friendly city policies, there are several factors that influence, namely: completeness of the facilities; Accessibility; Safety and comfort; Government commitment.
\end{abstract}

Keywords : Policies, Child Friendly Cities, Child Friendly Playroom Program

Corresponding author. Email. pivit.s.chandra@uin-suska.ac.id

How to cite this article. Chandra, P. Septiary \& Putri, S. S. Eka. (2021). Analisis Pelaksanaan Kebijakan Kota Layak Anak (Studi Kasus Pelaksanaan Program Ruang Bermain Ramah Anak di Ruang Terbuka Hijau Kacang Mayang Kota Pekanbaru). Jurnal Manajemen dan Ilmu Administrasi Publik (JMIAP) Jurusan Ilmu Administrasi Negara Fakultas Ilmu Sosial Universitas Negeri Padang, Volume 3 (1), Hal. 72-83.

http://jmiap.ppj.unp.ac.id

Copyright@2021. Published by Labor Jurusan Ilmu Administrasi Negara FIS UNP, Padang 
Pivit Septiary Chandra, Sonia Sischa Eka Putril Analisis Pelaksanaan Kebijakan Kota Layak Anak (Studi Kasus Pelaksanaan Program Ruang Bermain Ramah Anak di Ruang Terbuka Hijau Kacang Mayang Kota Pekanbaru)

\section{PENDAHULUAN}

Pada tahun 2030, pemerintah berkomitmen mencapai target Sustainable Development Goal atau SDG's khususnya terkait pembangunan anak. Bermacam strategi di tingkat nasional maupun daerah telah disusun untuk mencapai target yang sudah ditentukan. Target yang ingin dicapai diantaranya adalah penghapusan kemiskinan anak; tidak ada lagi anak-anak kekurangan gizi dan meninggal karena penyakit yang bisa diobati; menciptakan lingkungan yang ramah terhadap anak; memenuhi kebutuhan pendidikan anak khususnya pendidikan di usia dini; dan target lainya. Nasib masa depan anak-anak di Indonesia pada kurun waktu 13 tahun kedepan ditentukan oleh sejauh mana strategi yang disusun oleh pemerintah dapat diimplementasikan secara berkesinambungan.

Pemerintah menyadari pentingnya ketersediaan bermacam indikator anak. Sebagai asset pembangunan, maka pemerintah perlu berinvestasi secara intensif pada kesehatan dan kesejahteraan anak-anak Indonesia. Bagaimana dengan tumbuh kembang anak terkait dengan kesehatan dan nutrisi yang diperlukan, pendidikan dan kesejahteraan anak, lingkungan tempat anak tumbuh dan berkembang dan faktor-faktor lainnya. Beberapa hal tersebut merupakan penentu masa depan anak.

Dalam menyikapi dinamika berkehidupan sosial anak-anak yang berorientasi pada pembangunan anak, maka pemerintah melalui Kementerian Pemberdayaan Perempuan dan Perlindungan Anak (Kemen PPPA) memiliki 8 program prioritas perlindungan anak guna menjamin ketersediaan hak-hak anak dalam tumbuh kembanganya yaitu salah satunya adalah Peningkatan Sarana Publik Ramah Anak. Program tersebut merupakan bagian dari pengembangan Kota Layak Anak (KLA) yang merupakan suatu bentuk komitmen pemerintah dalam mewujudkan Good Governance atau tata kelola pemerintahan yang baik. Dalam (Peraturan Menteri Pemberdayaan dan Perlindungan Anak Republik Indonesia tentang Panduan Pengembangan Kabupaten/Kota Layak Anak, 2011) menjelaskan Panduan Pengembangan Kabupaten/Kota Layak Anak,KLA ialah Kabupaten/kota yang mempunyai system pembangunan berbasis hak anak melalui pengintegrasian komitmen dan dunia usaha yang terencana secara menyeluruh dan berkelanjutan dalam kebijakan, program dan kegiatan untuk menjamin hak anak.

Dalam pengelolaan Kota Layak Anak pemerintah kota Pekanbaru mengeluarkan Peraturan Walikota Pekanbaru Nomor 33 Tahun 2016 tentang Kebijakan Kota Layak Anak. Kebijakan tersebut bertujuan untuk meningkatkan komitmen pemerintah daerah, kecamatan, kelurahan, dan masyarakat, serta Dunia Usaha di wilayah Daerah dalam upaya mewujudkan pembangunan yang peduli terhadap anak, memenuhi serta melayani kebutuhan dan kepentingan terbaik bagi anak. Dalam program prioritas Kementerian Pemberdayaan Perempuan dan Perlindungan Anak terdapat tiga kegiatan pokok yaitu 1)Pemberdayaan perempuan; 2)Perlindungan Perempuan dan Anak; 3) Pemenuhan Hak Anak.

Ruang Bermain Ramah Anak merupakan salah satu program utama dari 3 program pokok Kementerian Pemberdayaan Perempuan dan Perlindungan Anak yaitu Pemenuhan Hak Anak deputi Bidang Tumbuh Kembang Anak. Proses tumbuh kembang yang merupakan proses utama, hakiki dan positif pada anak. Berbagai hasil penelitian menyebutkan bahwa masa usia dini merupakan periode emas bagi perkembangan anak dimana $50 \%$ perkembangan kecerdasan terjadi pada usia 0-4 tahun, 30\% berikutnya hingga usia 8 tahun (Permono,2013). Periode emas ini sekaligus merupakan periode kritis bagi anak dimana perkembangan yang didapatkan pada periode ini sangat 
Pivit Septiary Chandra, Sonia Sischa Eka Putri I Analisis Pelaksanaan Kebijakan Kota Layak Anak (Studi Kasus Pelaksanaan Program Ruang Bermain Ramah Anak di Ruang Terbuka Hijau Kacang Mayang Kota Pekanbaru)

berpengaruh terhadap perkembangan pada periode berikutnya hingga masa dewasanya.

Pekanbaru merupakan ibu kota dari Provinsi Riau yang tergabung menjadi anggota Kota Layak Anak (KLA) di tingkat Pratama sampai 2017 hal ini bentuk keseriusan pemerintah Kota Pekanbaru terhadap pemenuhan kebutuhan Anak di Kota Pekanbaru.

\section{Tabel 1. Jumlah Penduduk Remaja Kota Pekanbaru Menurut Kelompok Umur 2014-2018}

\begin{tabular}{ccccccc}
\hline $\mathrm{N}_{0}$ & $\begin{array}{c}\text { Kelompok } \\
\text { Umur }\end{array}$ & 2014 & 2015 & 2016 & 2017 & 2018 \\
\hline$(1)$ & $(2)$ & $(3)$ & $(4)$ & $(5)$ & $(6)$ & $(7)$ \\
1 & $0-4$ & 106.749 & 107.886 & 109.012 & 110.018 & 110.877 \\
2 & 5.9 & 90.013 & 92.175 & 94.233 & 96.430 & 98.660 \\
3 & $10-14$ & 84.169 & 85.856 & 87.316 & 88.513 & 89.658 \\
4 & $15-19$ & 99.341 & 100.346 & 101.860 & 103.787 & 105.760 \\
\hline & Total & 380.272 & 386.263 & 392.421 & 393.748 & 404.955 \\
\hline
\end{tabular}

Sumber: Data Olahan Peneliti dari Badan Pusat Statistik Pekanbaru

Berdasarkan Undang-Undang Nomor 35 Tahun 2014 tentang Perubahan Atas Undang-Undang Nomor 23 Tahun 2002 tentang Perlindungan Anak, pasal 1 ayat 1, yang dimaksud Anak adalah seseorang yang belum berusia 18 (delapan belas) tahun, termasuk anak yang masih dalam kandungan. Sebagaimana data atas dapat dilihat bahwa dari penduduk yang berumur 0-17 tahun merupakan tergolong remaja yang dari tahun 2014-2018 terus mengalami peningkatan, sehingga hal ini menjadi perhatian bagi pemerintah dalam urusan perkembangan anak/remaja yang sebagaimana telah dijelaskan di atas hal tersebut menjadi komitmen pemerintah.

Dengan pertumbuhan yang cukup tinggi program prioritas yang dirumuskan oleh Kementerian Pemberdayaan Perempuan dan Perlindungan Anak dan program Kota Layak Anak (KLA) yang telah di kembangkan oleh Kota Pekanbaru di harapkan bisa membantu dalam memenuhi hak anak sesuai dengan tujuan KLA itu sendiri yaitu untuk membangun inisiatif pemerintah Kota/ Kabupaten yang mengarahkan pada upaya transformasi konversi hak-hak anak (Convention on the Right of Child) dari kerangka hukum ke dalam definisi, strategi, dan intervensi pembangunan dalam bentuk kebijakan, program, dan kegiatan-kegiatan pembangunan yang ditunjukkan untuk pemenuhan hak-hak anak, pada suatu wilayah Kota/Kabupaten.

Berdasarkan berita online Sindonews yang di upload pada tanggal 6 september 2019 di informasikan bahwa Kota Pekanbaru provinsi Riau mendapat penghargaan atas penilaian tertinggi terhadap Ruang Bermain Ramah Anak (RBRA) dalam program Kota Layak Anak (KLA). Penilaian tersebut diberikan sesuai hasil penilaian yang dilakukan tim auditor dari KemenPPPA, yang mana Kota Pekanbaru dinilai sudah memenuhi 13 standarisasi penilaian Self Assessment dan audit dengan raihan angka 356.

\section{Gambar 1. Pekanbaru Raih Sertifikasi Tertinggi RBRA dari KemenPPPA}

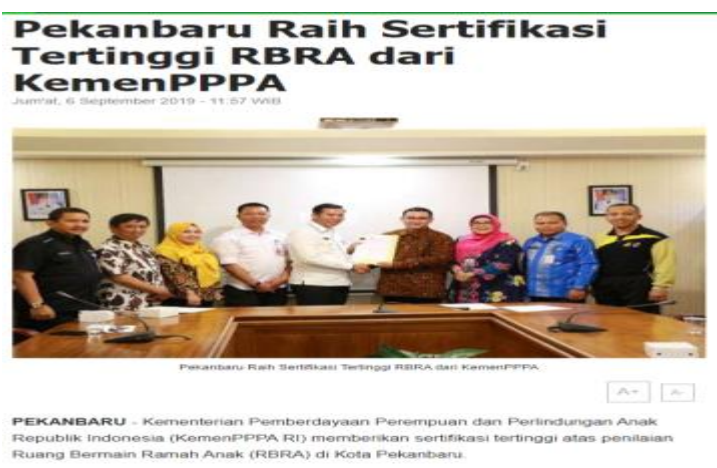

(Sumber:https://daerah.sindonews.com/rea d/1437056/174/pekanbaru-raih-sertifikasitertinggi-rbra-dari-kemenpppa1567745871)

Dengan diraihnya Pekanbaru menjadi kota yang menyediakan Ruang Bermain Ramah Anak bersertifikasi menjadi komitmen awal dalam membangun serta menyediakan hak anak dalam tumbuh kembang pada arena bermainnya. hal tersebut berbanding lurus dengan upaya pemerintah kota pekanbaru dalam 
Pivit Septiary Chandra, Sonia Sischa Eka Putri I Analisis Pelaksanaan Kebijakan Kota Layak Anak (Studi Kasus Pelaksanaan Program Ruang Bermain Ramah Anak di Ruang Terbuka Hijau Kacang Mayang Kota Pekanbaru)

mewujudkan masyarakat atau sumber daya manusia yang berkualitas sejak ini. Pada saat ini berdasarkan pernyataan Walikota Pekanbaru, Ruang Terbuka yang memiliki sertifikat layak anak di kota pekanbaru adalah Ruang Terbuka Hijau Kacang Mayang (sumber:https://m.situsriau.com/, 6 September 2019). untuk itu berdasarkan hal tersebut peneliti membuat penelitian yang berjudul "Analisis Pelaksanaan Kebijakan Kota Layak Anak (Studi Kasus Pelaksanaan Program Ruang Bermain Ramah Anak di Ruang Terbuka Hijau Kacang Mayang Kota Pekanbaru)

\section{TINJAUAN PUSTAKA \\ Kebijakan Publik}

Kebijakan merupakan serangkaian kegiatan yang mempunyai maksud atau tujuan tertentu yang diikuti dan dilaksanakan oleh seorang aktor atau sekelompok aktor yang berhubungan dengan suatu permasalahan atau suatu hal yang diperhatikan, James Anderson dalam Agustino (2008:7).

Menurut W.I Jenkins dalam Wahab (2012:15) mengemukakan kebijakan publik sebagai berikut:

"...Public policy is a complex phenomenom consisting of numerous desicions made by numerous individualy and organizations. it is often shaped by earlier policies and is frequently linked closely with other seemingly unrelated desicions" (Kebijakan publik merupakan sebuah fenomena kompleks yang terdiri dari banyak keputusan yang dibuat oleh banyak orang dan organisasi. kebijakan publik juga kerap kali terbentuk dari kebijakan-kebijakan yang telah ada dan juga sering berhubungan dengan keputusan yang lain yang diduga tidak berkaitan).

Dari pendapat ahli diatas dapat di diketahui bahwa kebijakan publik adalah fenomena yang terbentuk dengan kompleks terhadap keputusan-keputusan yang dibuat oleh individu atau secara berkelompok dan juga memang sudah ada atau kebijakan baru dengan tujuan yang sama atau tetap untuk menyelesaikan publik/masyarakat.

persoalan

Menurut Charles L. Cochran dan Eloise F. Malone dalam Nugroho (2012:121) yaitu : "Publik Policy consists of political desicions.

\section{IMPLEMENTASI KEBIJAKAN}

Studi Implementasi merupakan suatu kajian mengenai studi kebijakan yang mengarah pada proses pelaksanaan dari suatu kebijakan. Dalam praktiknya implementasi kebijakan merupakan suatu proses yang begitu kompleks bahkan tidak jarang bermuatan politis dengan adanya intervensi berbagai kepentingan. Untuk melukiskan kerumitan dalam proses implementasi tersebut dapat dilihat pada kenyataan yang dikemukakan oleh seorang ahli studi kebijakan Eugene Bardach dalam Agustino (2006:138), yaitu :

"...Adalah cukup untuk membuat sebuah program dan kebijakan umum yang kelihatannya bagus diatas kertas. Lebih sulit lagi merumuskannya dalam katakata dan slogan-slogan yang kedengarannya mengenakan bagi telinga para pemimpin dan para pemilih yang mendengarkannya. Dan lebih sulit lagi untuk melaksanakannya dalam bentuk cara yang memuaskan semua orang termasuk mereka anggap klien".

Pemahaman kebijakan menurut Daniel Mazmanian dan Paul Sabatier dalam buku dasar-dasar kebijakan public oleh Leo Agustino (2006:139) mendefinisikan Implementasi Kebijakan sebagai: "Pelaksanaan keputusan kebijakan dasar, biasanya dalam bentuk undang-undang, namun dapat pula berbentuk perintahperintah atau keputusan-keputusan eksekutif yang penting atau keputusan badan peradilan. Lazimnya, keputusan tersebut mendefinisikan masalah yang ingin diatasi, menyebutkan secara tegas tujuan atau sasaran yang ingin dicapai, dan berbagai cara untuk menstrukturkan atau mengatur proses impelentasinya". 
Pivit Septiary Chandra, Sonia Sischa Eka Putril Analisis Pelaksanaan Kebijakan Kota Layak Anak (Studi Kasus Pelaksanaan Program Ruang Bermain Ramah Anak di Ruang Terbuka Hijau Kacang Mayang Kota Pekanbaru)

Pada sisi lain Van Meter dan Van Horn dalam Agustino (2006), mendefinisikan implementasi kebijakan, sebagai: "Tindakan-tindakan yang dilakukan baik oleh individu-individu atau pejabat-pejabat atau kelompok-kelompok pemerintah atau swasta yang diarahkan pada tercapainya tujuan-tujuan yang telah digariskan dalam keputusan kebijaksanaan".

Dari tiga definisi tersebut diatas dapat diketahui bahwa implementasi kebijakan menyangkut tiga hal, yaitu: (1) adanya tujuan atau sasaran kebijakan; (2) adanya aktivitas atau kegiatan pencapaian tujuan; dan (3) adanya hasil kegiatan.

Berdasarkan uraian diatas dapat disimpulkan bahwa implementasi merupakan suatu proses yang dinamis, dimana pelaksanaan kebijakan melakukan suatu aktivitas atau kegiatan, sehingga pada akhirnya akan mendapatkan suatu hasil yang sesuai dengan tujuan atau sasaran kebijakan itu sendiri. Keberhasilan suatu implementasi kebijakan dapat diukur atau dilihat dari proses dan pencapaian tujuan hasil akhir. Hal ini tak jauh berbeda dengan apa yang diutarakan oleh Merrile Grindle (1980) sebagai berikut: "Pengukuran keberhasilan implementasi dapat dilihat dari prosesnya, dengan mempertanyakan apakah pelaksanaan program sesuai dengan yang telah ditentukan yaitu melihat pada Action program dari individual projects dan yang kedua apakah tujuan program tersebut tercapai".

Menurut George Edward III dalam Nugroho (2009) menegaskan bahwa masalah utama administrasi public adalah lack of attention to implementation. Dikatakanya, without effective implementation the decision of policymakers will not be carries out successfully. Edward menyarankan untuk memperhatikan empat isu pokok agar implementasi kebijakan menjadi efektif, yaitu communication, resource or attitudes, and bureaucratic strukturres.

Komunikasi berkenaan dengan bagaimana kebijakan dikomunikasikan pada organisasi dan/atau public, ketersediaan sumber daya untuk melaksanakan kebijakan, sikap dan tanggap dari para pihak yang terlibat, dan bagaimana struktur organisasi pelaksanaan kebijakan

Resources berkenaan dengan ketersediaan sumber daya pendukung, khususnya sumber daya manusia. Hal ini berkenaan dengan kecakapan pelaksana kebijakan public untuk carry out kebijakan secara efektif.

Disposition berkenaan dengan kesediaan dari para implementor untuk carry out kebijakan public tersebut. Kecakapan saja tidak mencukupi, tanpa kesediaan dan komitmen untuk melaksanakan kebijakan.

Struktur birokrasi berkenaan dengan kesesuaian organisasi birokrasi yang menjadi penyelenggara implementasi kebijakan publik. Tantangannya adalah bagaimana agar tidak terjadi bureaucratic fragmentation karena struktur ini menjadikan proses implementasi menjadi jauh dari efektif.

\section{Ruang Bermain Ramah Anak}

Anak merupakan setiap manusia yang berada di bawah usia delapan belas tahun. Konvensi hak anak adalah perjanjian antar bangsa-bangsa mengenai hak-hak anak. Hak-hak anak melekat dalam diri anak, hakhak anak merupakan hak asasi manusia dan hak anak dapat menjamin hak asasi anak. Anak di seluruh dunia adalah yang memiliki hak. Semua masyarakat harus mengetahui bahwa anak memiliki sejumlah hak yang sudah diakui agar menjadi landasan untuk perubahan kehidupan anak yang lebih baik. hal tersebut menjadi landasan atau pedoman bagi setiap Negara yang akan membuat kebijakan khususnya mengenai anak.

Kementerian Pemberdayaan Perempuan dan Perlindungan Anak merupakan perpanjangan tangan pemerintah pusat dalam mengurusi dan mengakomodir kebutuhan perempuan dan anak. Dalam program kementerian Pemberdayaan Perempuan dan Perlindungan Anak terdapat 
Pivit Septiary Chandra, Sonia Sischa Eka Putri I Analisis Pelaksanaan Kebijakan Kota Layak Anak (Studi Kasus Pelaksanaan Program Ruang Bermain Ramah Anak di Ruang Terbuka Hijau Kacang Mayang Kota Pekanbaru)

program prioritas yaitu program

Pemberdayaan Perempuan;

Perlindungan Perempuan dan Anak; (3)

Pemenuhan Hak Anak.

Pada program prioritas Kementerian Pemberdayaan Perempuan dan Perlindungan Anak tentang "Pemenuhan Hak Anak" di rumuskan sebuah konsep mengenai Kebijakan Pengembangan Kota Layak Anak yang diintegrasikan pada setiap daerah otonom Kabupaten/Kota di Indonesia.

Kota Layak Anak (KLA) adalah sistem pembangunan kabupaten/kota yang mengintegrasikan komitmen dan sumber daya pemerintah, masyarakat dan dunia usaha yang terencana secara menyeluruh dan berkelanjutan dalam kebijakan, program, dan kegiatan untuk pemenuhan hak-hak anak.

Adapun pentingnya mewujudkan KLA yaitu sebagai berikut:

1. Jumlah anak sekitar sepertiga dari total penduduk;

2. Anak merupakan modal dan investasi sumber daya manusia di masa yang akan datang, sekaligus sebagai generasi penerus bangsa;

3. Anak harus berkualitas agar tidak menjadi beban pembangunan;

4. Koordinasi dan kemitraan antar pemangku kepentingan terkait pemenuhan hak-hak anak harus diperkuat agar terintegrasi, holistik dan berkelanjutkan (Bandari Reni,2014)

Masa anak-anak merupakan jenjang kehidupan yang terjadi pada manusia di awal pertumbuhan yang berada pada masa antara 1-5 tahun. sebagaimana yang diungkapkan oleh Kartono, 1995 bahwa: "kanak-kanak pada periode ini mengalami masa peralihan (transisi) dari satu masa pertumbuhan dimana terjadi perubahan secara fisiologis sebagai hasil dari proses pematangan fungsi fisik ke periode yang lain ditandai dengan lonjakan tingkah laku yang kuat dan revolusioner".
Untuk itu hal yang berkenaan dengan tumbuh kembang anak harus di beri hal-hal yang positif dan membangun dari segi psikologi dan psikis anak. Beberapa hal lain yang perlu menjadi perhatian oleh keluarga dan bahkan pemerintah adalah bentuk kepercayaan dan kesempatan terhadap hak bermain pada anak di luar rumah tanpa pengawasan secara langsung di lingkungan fisik yang beragam dan menantang dengan kemudahan akses berlindung pada orang dewasa secara tidak langsung, serta memberikan peluang untuk berinteraksi, bermain di lingkungan alam terbuka maupun lingkungan buatan.

Adanya peraturan Undang-Undang Nomor 23 Tahun 2002 pasal 11 tentang Perlindungan anak menyatakan bahwa : "Setiap anak berhak untuk beristirahat dan memanfaatkan waktu luang, bergaul dengan anak yang sebaya, bermain, berekreasi dan berkreasi sesuai dengan minat, bakat dan tingkat kecerdasannya demi pengembangan diri”.

Hal diatas menjadi bukti tentang perlindungan terhadap hak anak atas ruang bermain yang dilindungi oleh UndangUndang, karenanya Pemerintah Pusat melalui Kementerian Pemberdayaan Perempuan dan Perlindungan Anak menerbitkan Kebijakan tentang Ruang Bermain Ramah Anak (RBRA) dalam bentuk pedoman Undang-Undang tentang perlindungan anak tersebut pada pasal 1 ayat 1 menyatakan bahwa anak adalah seorang yang belum pasti berusia 18 tahun, termasuk yang belum dilahirkan, dikelompokkan dalam 4 golongan yaitu: (1) Infant (Bayi 0-1 th); (2) Anak 1-3 tahun; (3) Anak 3-5 tahun; (4) Anak 6-9 tahun.

\section{METODE PENELITIAN}

Jenis penelitian ini adalah kualitatif dengan analis deskriptif. Penelitian kualitatif sebagai prosedur penelitian yang menghasilkan data deskriptif berupa katakata tertulis atau lisan dari orang-orang dan perilaku yang diamati dari fenomena yang terjadi. Kemudian (Moloeng:2007) 
Pivit Septiary Chandra, Sonia Sischa Eka Putri I Analisis Pelaksanaan Kebijakan Kota Layak Anak (Studi Kasus Pelaksanaan Program Ruang Bermain Ramah Anak di Ruang Terbuka Hijau Kacang Mayang Kota Pekanbaru)

mengemukakan bahwa penelitian deskriptif menekankan pada data berupa kata-kata, gambar dan bukan angka-angka yang disebabkan oleh adanya penerapan metode kualitatif. penelitian ini menggali fakta Implementasi Program Ruang Bermain Ramah Anak di Kota Pekanbaru. Teknik pengumpulan data dalam penelitian ini menggunakan studi literatur dengan mengumpulkan data-data dan dokumen dari berbagai referensi yang akan dijadikan rujukan.

\section{HASIL DAN PEMBAHASAN}

Analisis Pelaksanaan Kebijakan Kota Layak Anak (Studi Kasus Pelaksanaan Program Ruang Bermain Ramah Anak di Ruang Terbuka Hijau Kacang Mayang Kota Pekanbaru)

Anak merupakan bagian dari warga kota. PBB memperkirakan pada tahun 2025, 60 persen anak tinggal di kota (Kemenpppa,2016). Menurut David Sucher perancang kota dari Amerika Serikat (David,1995:65), anak seperti burung kenari di tambang batu bara. Mereka kecil, rentan dan butuh perlindungan. Akan tetapi sebagian besar dari jutaan anak yang hidup di kota belum merasa tenang dan nyaman melakukan kegiatan sehari-hari seperti bersekolah, bermain, dan berekreasi, terutama mereka yang tinggal di daerah kumuh dan pemukiman liar yang padat, dan perumahan yang kurang sehat serta kurang mendapatkan pelayanan umum seperti fasilitas air bersih, sanitasi dan pemuangan sampah.

Kondisi lain menggambarkan keterbatasan akses ke palayanan dasar anak seperti kesehatan, pendidikan, bermain, rekreasi, kenyaman menggunakan jalan, dan pedestrian. Hal ini menunjukkan bahwa kebijakan dan anggaran pemerintah kota di bidang anak belum menjadi prioritas dan masih terbatas.

Pada tahapan pembangunan, peran anak yang di proyeksikan sebagai calon pimpinan dan pemimpin bangsa perlu menjadi pertimbangan dan perhatian. Peran tersebut pun berkaitan dengan lingkungan kota sebagai pelayanan yang hal tersebut pun memiliki andil dalam pembangunan kota. Pada penelitian tentang "Persepsi Anak Mengenai Lingkungan Kota" yang dilakukan oleh Hamid Patilima (Hamid, 2004) di simpulkan bahwa dengan membangun sarana kebutuhan masyarakat, pemerintah kota mengnggap bahwa kebutuhan anakpun telah terwakili dan terpenuhi dengan sendirinya. Pengabdian pemerintah kota terhadap anak bukan hanya pada kebijakan dan anggaran yang terbatas, tetapi juga pada pelayanan dan penyediaan sarana kota yang berpengaruh pada tumbuh kembang anak.

Kota layak anak yang menjadi program pemerintah dalam mewujudkan penyediaan sarana kota pendukung tumbuh kembang anak di perkotaan menyediaan layanan berupa Ruang terbuka Hijau yang mengaplikasikan faktor ramah anak sehingga menghasilkan suatu lokasi Ruang terbuka hijau yang berupa Ruang Bermain Ramah Anak. Pekanbaru menjadi salah satu ibukota provinsi di Indonesia memiliki Ruang Terbuka Hijau (RTH) yang mendapat sertifikasi sebagai Ruang Bermain Ramah Anak oleh Kementerian Pemberdayaan Perempuan dan Perlindungan Anak tahun 2019.

Berdasarkan pernyataan Wali kota pekanbaru Firdaus MT yang di publikasi oleh media online bahwa Pekanbaru baru memiliki satu Ruang Terbuka yang Ramah Anak. Berikut adalah gambar informasinya.

\section{Gambar 2. Ruang Terbuka Ramah Anak di Pekanbaru tahun 2019}

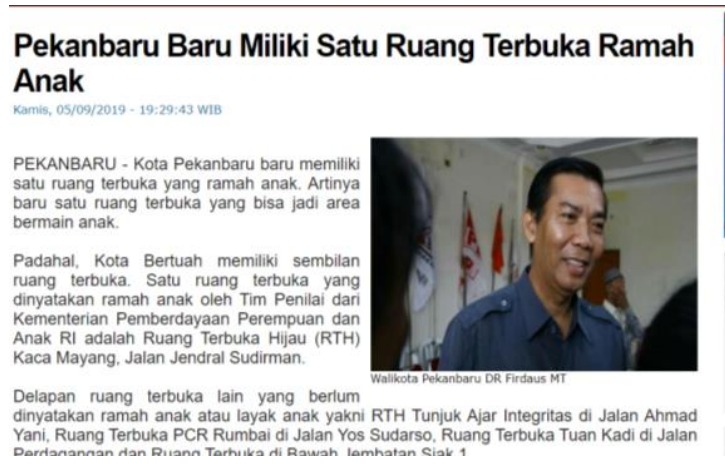


Pivit Septiary Chandra, Sonia Sischa Eka Putril Analisis Pelaksanaan Kebijakan Kota Layak Anak (Studi Kasus Pelaksanaan Program Ruang Bermain Ramah Anak di Ruang Terbuka Hijau Kacang Mayang Kota Pekanbaru)

Berdasarkan gambar diatas dapat di lihat bahwa, Pekanbaru memiliki Sembilan Ruang terbuka namun hanya satu ruang terbuka yang dinyatakan aman untuk dijadikan tempat bermain dan wadah tumbuh kembang anak yang aman digunakan bagi anak-anak yaitu Ruang Terbuka Hijau Kacang Mayang. hal tersebut dinyatakan oleh tim penilai dari Kementerian Pemberdayaan Perempuan dan Anak RI. Untuk delapan ruang terbuka hijau lainnya belum dinyatakan ramah anak atau layak anak. kedelapan Ruang Terbuka hijau tersebut yaitu :

1. Ruang Terbuka Hijau Tunjuk Ajar Integritas

2. Ruang terbuka Politeknik Caltex Riau

3. Ruang Terbuka Tuan Kadi

4. Ruang Terbuka di bawah jembatan siak 1

5. Ruang Terbuka Kayu putih

6. Ruang Terbuka Jalan Diponegoro

7. Ruang Terbuka Cinta Raja

8. Ruang Terbuka Purna MTQ

9. Ruang Terbuka Ramah Anak

Di dalam kebijakan Peraturan Menteri

Pemberdayaan Perempuan dan Perlindungan Anak nomor 12 tahun 2011 tentang indikator kota layak anak menerangkan bahwa dalam mewujudkan kota layak anak terdapat klaster hak anak yang meliputi:

1. Hak sipil dan kebebasan;

2. Lingkungan keluarga dan pengasuhan alternatif;

3. Kesehatan dasar dan kesejahteraan;

4. Pendidikan, pemanfaatan waktu luang dan kegiatan budaya;

5. Perlindungan khusus.

Terkhusus dalam klaster 4 (pendidikan, pemanfaatan waktu luang dan kegiatan budaya) terdapat beberapa indikator pencapaian yaitu:

1. Angka partisipasi pendidikan anak;

2. Persentase wajib belajar pendidikan 12 tahun;

3. Persentase sekolah ramah anak;
4. Jumlah sekolah yang memiliki program, sarana dan prasarana perjalanan anak ke dan dari sekolah;

5. Tersedia fasilitas untuk kegiatan dan rekreatif yang ramah anak, diluar sekolah, yang dapat diakses semua anak.

Urusan pemenuhan kebutuhan anak pada penyediaan ruang terbuka ramah anak termasuk dalam klaster 4 poin e. Yang dalam hal ini dijelaska bahwa yang dimaksud dengan fasilitas kreatif dan rekreatif adalah sarana dan prasarana yang disediakan untuk mengembangkan minat bakat anak, memanfaatkan waktu luang serta menjadi media ekspresi yang berada di luiar sekolah, baik yang disediakan oleh pemerintah, masyarakat maupun dunia usaha. Contohnya adalah sanggar, kegiatan seni budaya, taman kota, taman cerdas, taman teknologi, museum, dan fasilitas olahraga.

Dari indikator tersebut dapat disimpulkan bahwa untuk memenuhi kelengkapan ruang terbuka ramah anak harus disesuaikan dengan kebutuhan anak dalam peningkatan kreatifitas dan pengembangan bakat anak yang baik dan aman digunakan untuk anak sedangkan yang dikatakan ramah anak berarti aman untuk anak, sehingga segala faktor dan kelengkapannya harus aman untuk digunakan oleh anak di ruang terbuka.

Ruang terbuka kacang mayang dinyatakan ramah anak karena fasilitas, sarana dan prasarana yang tersedia tidak membahayakan anak-anak yang menggunakan fasilitasnya. RTH Taman Kaca Mayang merupakan taman kota di Kota Pekanbaru yang cukup ramai dikunjungi oleh masyarakat, berada di salah satu kawasan permukiman serta perdagangan dan jasa membuat taman ini dapat diakses dengan mudah baik dengan menggunakan kendaraan pribadi maupun kendaraan umum. Selain dapat diakses dengan mudah, taman ini juga memiliki berbagai fasilitas taman yang menjadi faktor penarik pengunjung diantaranya 
Pivit Septiary Chandra, Sonia Sischa Eka Putri I Analisis Pelaksanaan Kebijakan Kota Layak Anak (Studi Kasus Pelaksanaan Program Ruang Bermain Ramah Anak di Ruang Terbuka Hijau Kacang Mayang Kota Pekanbaru)

berbagai peralatan bermain, tempat duduk, pedagang kaki lima (PKL) dan lain sebagainya. taman ini paling ramai dikunjungi pada akhir pekan, sekitar pada pukul 07.00-12.00 WIB dan 15.00-17.00.

Prinsip kebijakan kota layak anak :

a. Non Diskriminasi yaitu tidak membedakan suku,ras,agama,jenis kelamin status social, status ekonomi, asal usul, kondisi fisik maupun psikis anak

b. Kepentingan terbaik anak yaitu mewajibkan kepentingan terbaik bagi anak sebagai pertimbangan dalam setiap pengambilan keputusan yang dilakukan oleh pemerintah daerah, kecamatn, kelurahan dan lembaga lainnya yang berhubungan langsung maupun tidak langsung dengan baik.

c. Hak untuk hidup, kelangsungan hidup dan perkembangan yaitu melindungi hak asasi anak sebagai hak dasar dalam kehidupan anak yang dilindungi oleh negara, pemerintah daerah , masyarakat, keluarga dan orang tua ; dan

d. Penghargaan terhadap pendapat anak yaitu penghormatan atas hak hak anak untuk berpartispasi dan menyatakan pendapat dalam pengambilan keputusan teruratama jika menyangkut hal-hal mempengaruhi kehidupan anak.

Hhasil observasi lapangan, fasilitasfasilitas yang tersedia di taman RTH Taman Kaca Mayang, diantaranya berbagai peralatan permainan, taman main anak, ada juga tempat kawasan dilarang merokok yang mana kawasan ini sangat dekat dengan kawasan taman bermain anak-anak, gazebo, tempat duduk, lampu taman, tempat sampah, toilet. Namun di taman ini belum tersedia jalur aksesibilitas bagi anak difabel, peralatan permainan yang ergonomis bagi anak difabel dan belum ada SDM/pengawas yang ramah anak sehingga pendamping anak-anak yang bermain di taman ini harus mengawasi dengan benar.
Gambar 3. Fasilitas Bermain Anak

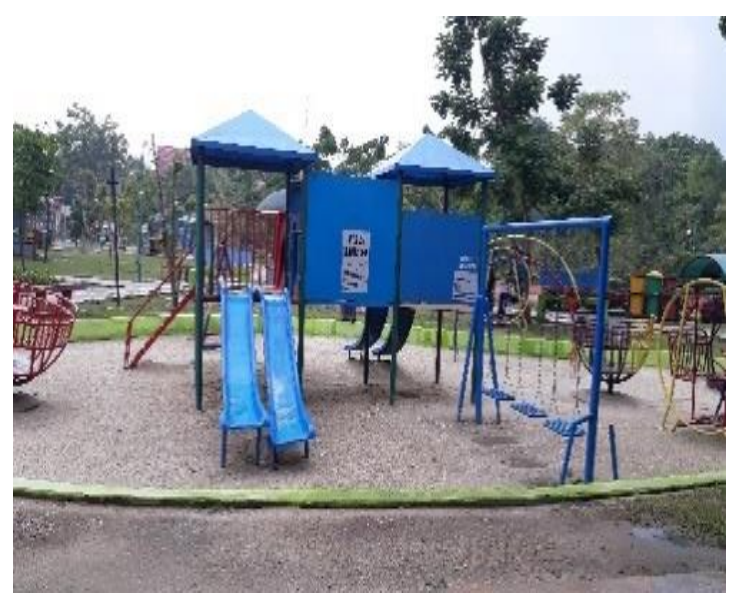

Di taman bermain anak ini terdiri dari ayunan, prosotan, puturan, climbing dan sebagainya. Ini untuk usia 2-10 tahun kegunaannya sebagai Melatih keberanian akan ketinggian:

a) Melatih menjaga keseimbangan

b) Stimulasi motoric kasar pada anak

c) Pembelajaran untuk bermain bergantian, antri dan berbagi

Alat-alat tersebut di gunakan untuk melatih keseimbangan dan kecerdasan anak dalam berinteraksi sosial dan pertahanan diri dalam melewati halang rintangan. Dalam pengamatan penulis, fasilitas tersebut di berlakukan untuk anak-anak namun juga tetap berada dalam pengawasan orangtua. Fasilitas ini sangat aman ditandai dengan belum adanya korban dari anakanak saat menggunakan alat tersebut.

\section{Gambar 4. Gazebo}

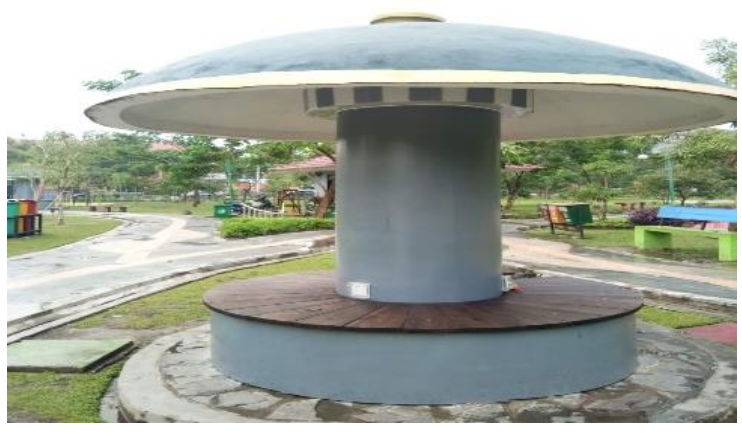

Menurut Wikipedia, gazebo adalah salah satu fasilitas dengan ruang-rungan terbuka sebagai alternative tempat berkumpul dan melakukan kegiatan santai bersama anggota 
Pivit Septiary Chandra, Sonia Sischa Eka Putri I Analisis Pelaksanaan Kebijakan Kota Layak Anak (Studi Kasus Pelaksanaan Program Ruang Bermain Ramah Anak di Ruang Terbuka Hijau Kacang Mayang Kota Pekanbaru)

keluarga lainnya, banyak juga yang menyebut saung karena digunakan untuk tempat santai.Di Gazebo ini digunakan untuk tempat santai, berteduh dan bisa digunakan untuk kegiatan seperti charger hp karena disitu ada tempat colokan. Hal ini sangat membantu untuk tempat berteduh anak dan berinteraksi dengan anak dan keluarga.

\section{Gambar 5. Tempat Sampah}

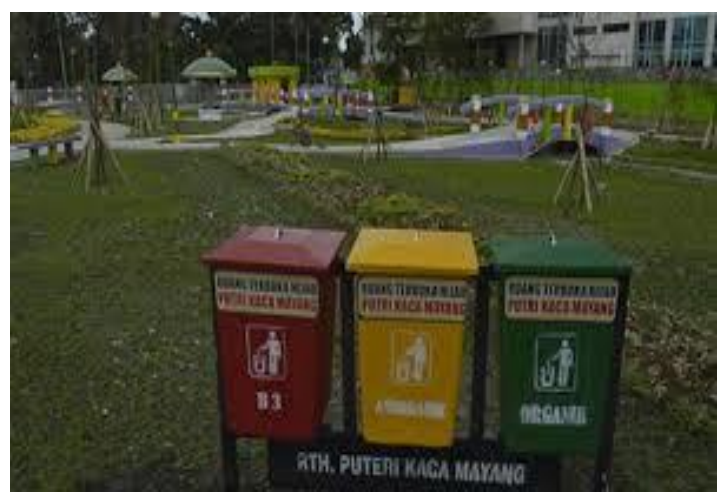

Tempat sampah disini disediakan 3 tempat yaitu:

a) Warna hijau untuk sampah organik. Sampah Organik adalah golongan sampah yang mudah membusuk. seperti daun-daun yang berguguran, kertas, kayu, sisa makanan basi dan lain-lain.

b) Warna kuning untuk sampah anorganik. Jenis sampah ini merupakan sisa-sisa proses produksi seperti fiber, plastik, kaca kaleng dan lain-lain.

c) Warna merah untuk sampah yang mengandung Bahan-bahan Beracun dan berbahaya (B3). Contoh-contoh sampah B3 adalah baterai bekas, bahan-bahan kimia, sarung tangan bekas yang mengandung minyak atau oli, dan lain sebagainya.

Fasilitas ini sedia kan untuk menjaga kebersihan lingkungan dan mengedukasi anak-anak serta pengunjung tentang sampah dan beberapa golongan sampah. Karena setiap sampah dari setiap golongannya memiliki penanganan yang berbeda.

\section{Gambar 6. Simbol}

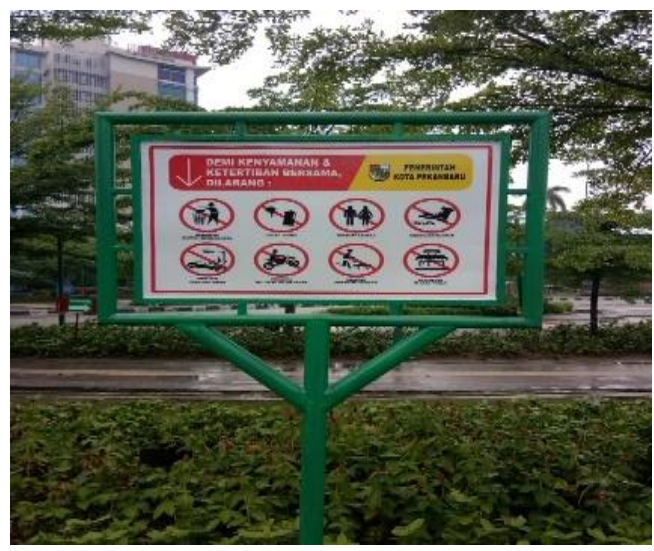

(a)

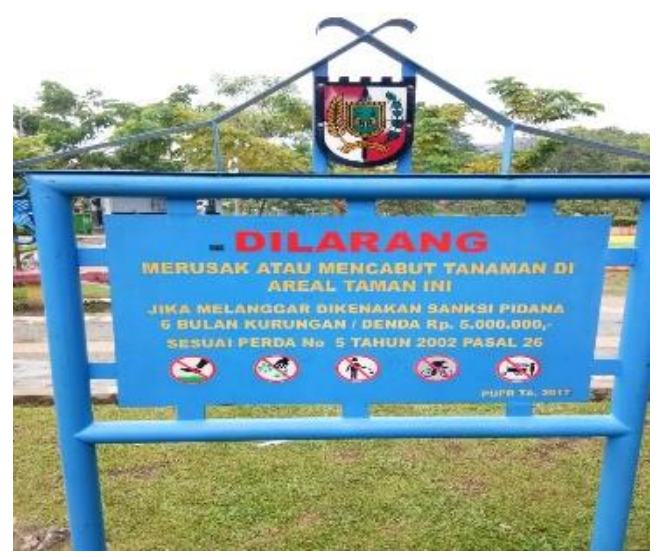

(b)

Dalam observasi penulis, penulis mendapati tersediannya papan-papan yang berisi informasi berupa simbol-simbol peringatan bagi pengunjung taman agar dapat menaatinya untuk ketertiban dan keamanan lingkungan. Pada keterangan simbol disini ditujukan untuk beberapa larangan yang tidak boleh dilakukan di taman ini seperti dilarang merusak tanaman dan sarana prarana.

Dikarenakan ruang terbuka hijau kacang mayang ini sangat ramah anak dan pengunjung pada umumnya, untuk itu segala aktifitas yang dapat mengganggu seperti mengganggu kesehatan pengunjung dan kesehatan lingkungan diberi 
Pivit Septiary Chandra, Sonia Sischa Eka Putri I Analisis Pelaksanaan Kebijakan Kota Layak Anak (Studi Kasus Pelaksanaan Program Ruang Bermain Ramah Anak di Ruang Terbuka Hijau Kacang Mayang Kota Pekanbaru)

peringatan, sepeti halnya peringatan di larang merokok.

\section{Gambar 7. Kawasan Dilarang Merokok}

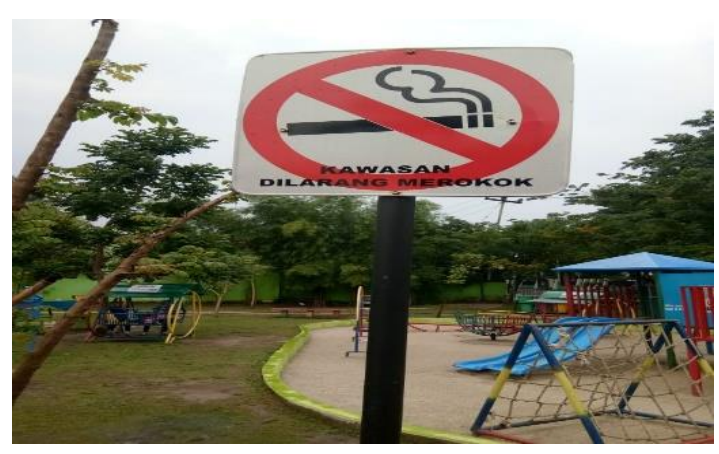

Merokok sangat mengganggu dan merusak sistem pernafasan manusia khususnya anak-anak. Sebagian pengunjung Ruang Terbuka Hijau ini merupakan anak-anak. Untuk itu sebagaimana komitmen pemerintah daerah yang tertuang didalam Peraturan Walikota Pekanbaru Nomor 33 Tahun 2016 tentang Kebijakan Kota Layak Anak untuk memfasilitasi kota pekanbaru dengan ketersediaan Ruang Terbuka Hijau yang berpedoman pad keinganan kota pekanbaru mewujudkan kota layak anak, maka Ruang Terbuka Hijau Kacang Mayang Pekanbaru pun harus konsisten menciptakan lingkungan yang ramah anak dengan membebaskan area dengan asap rokok. Hal ini diwujudkan dengan membuat papan larangan merokok di beberapa area Ruang Terbuka Hijau Kacang Mayang Pekanbaru.

\section{Faktor-faktor yang mempengaruhi Pelaksanaan Kebijakan Kota Layak Anak (Studi Kasus Pelaksanaan Program Ruang Bermain Ramah Anak di Ruang Terbuka Hijau Kacang Mayang Kota Pekanbaru)}

1. Faktor kelengkapan fasilitas

Untuk menciptakan ruang terbuka hijau yang ramah anak maka dibutuhkan fasilitas yang dapat mendukung tumbuh kembang anak dan mengembangkan daya kreatifitas anak di lapangan terbuka dan ditempat umum. Fasilitas yang dibutuhkan pun harus aman terhadap jangkauan anak-anak agar tidak mencelakai anai ketika bermain dan bersosialisasi.

2. Aksesibilitas

Ruang Terbuka Hijau (RTH) perkotaan adalah bagian dari ruang terbuka suatu wilayah perkotaan yang diisi oleh tanaman, tumbuhan dan vegetasi. RTH memiliki fungsi ekologis yaitu dapat meningkatkan kualitas air tanah, mencegah banjir, pengaturan iklim mikro dan mengurangi polusi udara (Malingkas, Johanis. Urgennya Ruang Terbuka Hijau di Perkotaan.

https://www.kompasiana.com/johanisalbert malingkaspacaran/5d4a598b0d823016e70f 2083/urgennya-ruang-terbuka-hijau-diperkotaan. 12 Februari 2020). Fungsi sosial ekonomi nya menyediakan ruang interaksi sosial, saran rekreasi dan sebagai landmark kota. Untuk itu RTH itu haruslah tempat yang mudah di akses oleh masyarakat umum, agar fungsi RTH dapat tercapai sebagaimana mestinya.

3. Keamanan dan kenyamanan

Anak-anak haruslah mendapatkan perhatian yang khusus dan lebih dalam tumbuh kembangnya. Untuk itu agar terwujudnya Kota Layak Anak yang di wujudkan melalui Ruang Terbuka Hijau Ramah Anak harus mengutamakan keamanan $\mathrm{n}$ kenyaman. Hal ini dapat menjadikan alternative anak dalam mengisi keseharianya dan untuk menghindari pengaruh teknologi yang terlalu mendominasi hari-hari anak

4. Komitmen Pemerintah

Dengan diberikankanya penilaian terhadap Ruang terbuka Hijau Kacang Mayang oleh Kementerian Pemberdayaan Perempuan dan Anak RI merupakan komiten pemerintah dalam mewujudkan kota layak anak di Kota Pekanbaru.

\section{PENUTUP}

Pelaksanaan Kebijakan Kota Layak Anak (Studi Kasus Pelaksanaan Program Ruang Bermain Ramah Anak di Ruang Terbuka Hijau Kacang Mayang Kota 
Pivit Septiary Chandra, Sonia Sischa Eka Putri I Analisis Pelaksanaan Kebijakan Kota Layak Anak (Studi Kasus Pelaksanaan Program Ruang Bermain Ramah Anak di Ruang Terbuka Hijau Kacang Mayang Kota Pekanbaru)

Pekanbaru) sudah berjalan dengan baik. hal ini ditandai dengan tersediannya fasilitas, sarana dan prasarana yang telah mumpuni untuk dijadikan Ruang Terbuka Hijau Ramah anak. memperoleh penilaian yang baik dan ditetapkan Ruang Terbuka Hijau Kacang Mayang Pekanbaru layak anak mejadi pembuktian berlangsungnya komitmen pemerintah dalam mewujudkan Kota layak Anak Melalui penyediaan Ruang Terbuka Hijau Ramah Anak.

Dalam melaksanakan kebijakan kota layak anak terdapat beberapa faktor yang mempengaruhi yaitu (1) kelengkapan fasilitas; (2) Aksesibilitas; (3) Keamanan dan kenyaman; (4) Komitmen Pemerintah.

Diperlukannya pengembangan terhadap kebijakan Kota Layak Anak untuk membuat pedoman Ruang Terbuka Hijau (RTH) yang Ramah Anak atau Ruang bermain Ramah Anak, agar perwujudaanya jelas dan dapat diikuti oleh pihak lainnya dalam mewujudkan kebutuhan anak akan ruang public atau taman bermain di daerah perkotaan.

\section{DAFTAR KEPUSTAKAAN}

Abdul Wahab, Solichin. 2012. Analisis Kebijakan: Dari Formulasi ke penyusunan.

Agustino, Leo. 2008. Dasar-dasar Kebijakan Publik. Alfabeta: Bandung.

https://daerah.sindonews.com/read/143705

6/174/pekanbaru-raih-sertifikasitertinggi-rbra-dari-kemenpppa1567745871).

https://m.situsriau.com/, 6 September 2019

Kartini Kartono. 1995. Psikologi Anak (Psikologi Perkembangan). Bandung : CV Mandar Maju.

Model-Model Implementasi Kebijakan Publik. Jakarta: PT. Bumi Aksara.

Nugroho D, Riant. 2009. Kebijakan Publik, Formulasi, Implementasi, dan
Evaluasi.Jakarta:Gramedia.

Peraturan Menteri Pemberdayaan dan Perlindungan Anak Republik Indonesia tentang Panduan Pengembangan Kabupaten/Kota Layak Anak, 2011.

Peraturan Walikota Pekanbaru Nomor 33 Tahun 2016 tentang Kebijakan Kota Layak Anak.

Permono, hendarti.2013. Peran Orangtua Dalam Optimalisasi Tumbuh Kembang Anak Untuk Membangun Karakter Anak Usia Dini. Publikasi Ilmiah. Hal 34-37.

Undang-Undang Nomor 35 Tahun 2014 tentang perlindungan anak. 